\title{
Sunflower crop: environmental-friendly and agroecological
}

\author{
Philippe Debaeke ${ }^{1, *}$, Laurent Bedoussac ${ }^{2}$, Catherine Bonnet $^{1}$, Emmanuelle Bret-Mestries $^{3}$, Célia Seassau ${ }^{4}$, \\ André Gavaland $^{5}$, Didier Raffaillac ${ }^{1}$, Hélène Tribouillois ${ }^{1}$, Grégory Véricel ${ }^{1}$ and Eric Justes ${ }^{1}$ \\ ${ }^{1}$ Inra, UMR AGIR 1248, CS 52627, 31326 Castanet-Tolosan, France \\ 2 ENSFEA, UMR AGIR 1248, CS 52627, 31326 Castanet-Tolosan, France \\ 3 Terres Inovia, Centre Inra de Toulouse, CS 52627, 31326 Castanet-Tolosan, France \\ 4 EI Purpan, UMR AGIR 1248, CS 52627, 31326 Castanet-Tolosan, France \\ ${ }^{5}$ Inra, Unité expérimentale de Toulouse-Auzeville, CS 52627, 31326 Castanet-Tolosan, France
}

Received 7 February 2017 - Accepted 29 March 2017

\begin{abstract}
Sunflower (Helianthus annuus L.) crop is often labelled as environmental-friendly for many objective reasons: limited amounts of $\mathrm{N}$ fertiliser, no irrigation, and limited use of pesticides. In addition, sunflower has a potential for providing multiple ecosystem services in diverse cropping systems (e.g. pollinators feeding). However agroecological innovations have been less developed or disseminated than for cereals or oilseed rape. Based on results from the sunflower research consortium in Toulouse (Mestries and Debaeke. 2016. Journées d'échanges Tournesol, 28 et 29 juin 2016, Toulouse (France)), we illustrate some innovating and promising approaches for more agroecological practices in sunflower cropping. Our results suggested that: integrated crop management could be proposed to limit the use of pesticides and mitigate crop damages; cover crops could be used as biofumigants to control soilborne diseases in sunflower; intercropping sunflower with soybean could be a valuable option for maximizing resource-use efficiency in low-input environments; sunflower yield could be maintained at good level in very low input cropping systems. Previous examples point out how agroecological principles could be applied to sunflower crop to improve its production in low-input conditions, and enhance the ecosystem services deliverable by this oilseed crop.
\end{abstract}

Keywords: cultural control / intercropping / ecosystem services / cropping systems / low-input

Résumé - La culture de tournesol : respectueuse de l'environnement et agroécologique. La culture de tournesol (Helianthus annuus L.) est souvent qualifiée de respectueuse de l'environnement en raison de sa faible dépendance aux apports d'engrais, à l'eau d'irrigation et aux applications de pesticides en végétation. Par ailleurs, le tournesol contribue à de nombreux services écosystémiques au premier rang desquels l'alimentation des pollinisateurs. Cependant, très peu d'innovations agroécologiques ont été mises en avant sur cette culture contrairement à ce qui a été développé en céréales ou en colza. En nous basant sur les travaux récents du consortium de recherche sur le tournesol basé à Toulouse (Mestries et Debaeke. 2016. Journées d'échanges Tournesol, 28 et 29 juin 2016, Toulouse (France)), nous illustrerons plusieurs approches innovantes et prometteuses pour augmenter la performance agroécologique de la culture de tournesol. Ainsi nos résultats montrent que: des méthodes de protection intégrée peuvent être proposées pour limiter l'application de pesticides et atténuer les pertes de rendement; des cultures intermédiaires (brassicacées) pourraient être utilisées pour la biofumigation des sols et le contrôle de maladies telluriques en tournesol; l'association culturale avec le soja pourrait constituer une option intéressante pour maximiser l'utilisation des ressources en bas intrants; le rendement du tournesol peut être maintenu à un bon niveau dans des systèmes à très bas niveaux d'intrants. Les exemples précédents illustrent comment les principes de l'agroécologie peuvent également être appliqués au tournesol pour améliorer la production dans les situations à bas niveaux d'intrants et plus largement les services écosystémiques apportés par la culture.

Mots clés : contrôle cultural / cultures associées / services écosytémiques / systèmes de culture / bas niveaux d'intrants

\footnotetext{
* Corresponding author: philippe.debaeke@inra.fr
} 


\section{Introduction}

Sunflower (Helianthus annuus L.) crop is often labelled as 'environmental-friendly' for many objective reasons (Blanchet, 1992; Ceccon et al., 2000; Pilorgé, 2010). The crop requires a limited amount of $\mathrm{N}$ fertiliser $\left(56 \mathrm{~kg} . \mathrm{ha}^{-1}\right)$ (Agreste, 2014) which makes it a low emitter of greenhouse gases (either directly or not) as compared to cereals and oilseed rape (BIO IS, 2010). Generally grown as a rainfed crop ( $~ 95 \%$ of sunflower-sown area in France is not irrigated), it needs only limited water amounts $(\sim 50 \mathrm{~mm})$ in the situations where supplemental irrigation is applied (Champolivier et al., 2011). Except herbicides, very few other pesticides (fungicides, insecticides) are sprayed over sunflower crops. Consequently the Treatment Frequency Index (TFI) is pretty low for sunflower compared to winter crops: 1.7 instead of 3.8 for wheat and 5.5 for oilseed rape (Agreste, 2013). In addition, sunflower is grown worldwide as a non-genetically modified crop.

Average organic yield may reach up to $90 \%$ of conventional one in sunflower (Lieven and Wagner, 2012). Therefore this crop is the main oilseed species grown in organic systems (15000 ha in France) which still highlights its adaptation to ecological agriculture using no pesticides and no mineral fertiliser. Mechanical weed control is feasible as row widths are greater than $50 \mathrm{~cm}$; even in conventional agriculture, mechanical weed control (hoeing) is practised in more than $40 \%$ of the fields. Generally, the energy balance of sunflower crop is relatively low but could be improved with reduced tillage. However, ploughing is still widely used as primary tillage $(74 \%$ in 2011$)$ because sunflower needs uncompacted soils for the establishment of its tap root system (Lecomte and Longueval, 2013).

As was stated by several authors, sunflower has a potential for providing multiple ecosystem services in diverse cropping systems (Jones and Sieving, 2006; Franco et al., 2016). The crop is a crucial source of pollen and nectar in early summer for the activity of pollinators especially honeybees (Delaplane and Mayer, 2000). Its contribution to the aesthetic value of landscape should be highlighted although this service looks difficult to evaluate properly. In the present and future context of climate change and variability, where more severe and more frequent droughts are expected in southern France, sunflower cropping offers a wide range of options for adaptation (Debaeke et al., 2017).

Although sunflower crop is considered by farmers as cheap, rustical (tolerant to water stress) and easy to manage, and constitutes a favourable preceeding crop for cereals (Lecomte and Nolot, 2011), it suffers from its low productivity due to a range of limiting factors (birds, fungal diseases, low and uneven plant population..) (Jouffret et al., 2011). Consequently, cultivated areas are stagnating or decreasing and the ecosystem services that are provided by the crop do not compensate for its lack of competitiveness. As a late springsown crop, sunflower could break winter crop rotations with benefits for the non chemical control of weeds and soil-borne diseases in cereals and oilseed rape. However it should not be grown too frequently as currently done in the traditional production basins (e.g. Occitanie region) in order to prevent the setting up of fungal diseases inoculum and maintain the sustainability of sunflower-based cropping systems.
Agroecology is based on several principles including the use of intra-field and intra-farm diversity in space and time in order to increase resource-use efficiency and resilience through variety and crop mixtures, cover crops, diversified crop rotations, and agroforestry among others (Altieri and Rosset, 1995; Duru et al., 2015). The substitution of pesticides by cultural and genetic control is also a basic component of agroecology. Conservation agriculture based on minimum soil disturbance, retention of crop residues, continuous soil covering with cash or service crops or organic mulch, diversified crop rotations and plurispecific stands is also suggested as an additional component of agroecological systems (Brouder and Gomez-Macpherson, 2014; Craheix et al., 2016).

Although sunflower owns the features of an ecological crop, agroecological innovations applied to this crop have not been extensively reported in the literature, probably because sunflower is a relatively minor field crop mainly grown in drought-prone areas or still under low-input management. In such situations, the motivation and opportunity to change current practices and adopt substitutive ones are less developed. In addition, as crop environmental impacts are limited and the application of pesticides reduced, agroecology was probably not identified as a priority. However, some specific traits of sunflower plants could facilitate the application of agroecological principles in crop management: e.g. morphological plasticity, stress tolerance and pollen production. The benefits of sunflower in nutrient cycling could also be mentioned, as the deep root system can absorb water and nutrients in the deeper layers of the soil (Connor and Hall, 1997; Angadi and Entz, 2002) and the fast degradation of cultural debris can deliver these nutrients rapidly into the later crop (Rodriguez-Lizana et al., 2010; Babu et al., 2014).

Based on results from the sunflower research Inra-Terres Inovia consortium in Toulouse (Mestries and Debaeke, 2016), we will illustrate some innovating and promising approaches for some more agroecological practices in sunflower cropping. Following results will show that (i) integrated crop management could be proposed to limit the use of pesticides and mitigate crop damages; (ii) cover crops (Brassicas) could be used as biofumigants to control soilborne diseases in sunflower; (iii) intercropping sunflower with soybean is an option for maximizing resource-use efficiency in low-input environments; (iv) sunflower yield is maintained at good level in very low input cropping systems.

\section{Cultural control to reduce the use of pesticides and face technical impasses in fungal disease management}

\subsection{Main fungal diseases in sunflower}

The main fungal diseases of sunflower crop in France are black stem disease (Phoma macdonaldii), downy mildew (Plasmopara halstedii), Phomopsis stem canker (Phomopsis helianthi), white mold (Sclerotinia sclerotiorum) and verticillium wilt (Verticillium dahliae).

Each year, the incidence of each disease varies at territorial level - see for example in southwestern France as illustrated in Figure 1 (Chambre d'agriculture Occitanie, 2016) - and at plot level, with different proportions of plants affected by each of 


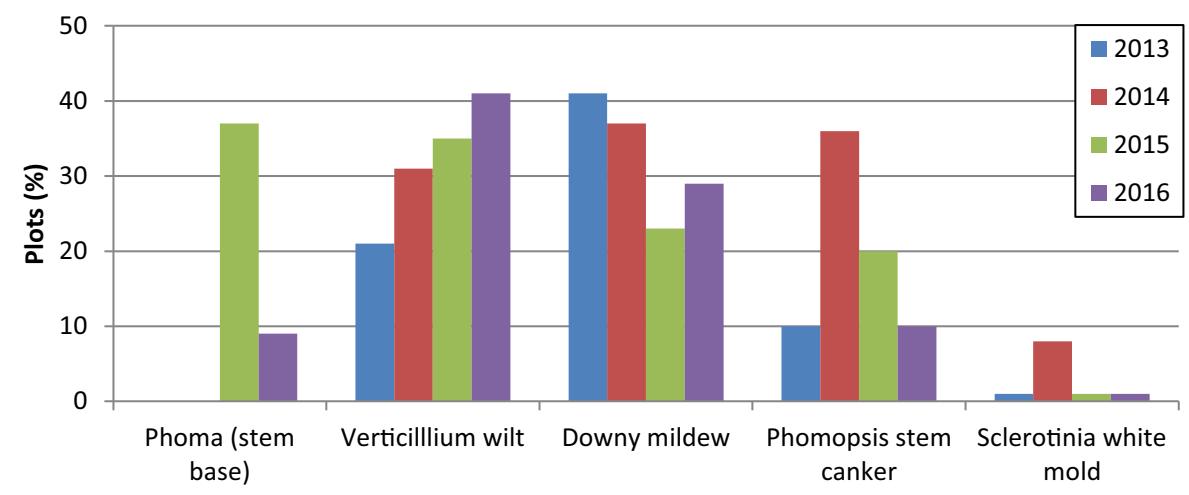

Fig. 1. Percentage of farmer's sunflower fields with fungal diseases in the south-west of France from 2013 to 2016 (Terres Inovia, SRAL MidiPyrénées and FREDON Aquitaine survey, 350 to 450 plots each year). Source: Chambre d'agriculture Occitanie (2016).

Table 1. Efficacy of control methods (from Aubertot et al., 2005 and Seassau et al., 2016).

\begin{tabular}{|c|c|c|c|c|c|}
\hline & $\begin{array}{l}\text { Downy } \\
\text { mildew }\end{array}$ & $\begin{array}{l}\text { Verticillium } \\
\text { wilt }\end{array}$ & $\begin{array}{l}\text { Phoma premature } \\
\text { ripening }\end{array}$ & $\begin{array}{l}\text { Phomopsis } \\
\text { stem canker }\end{array}$ & $\begin{array}{l}\text { Sclerotinia } \\
\text { white mold }\end{array}$ \\
\hline Genetic control & +++ & +++ & + & +++ & ++ \\
\hline Physical control & - & + & - & - & - \\
\hline Biological control & - & - & - & - & + \\
\hline Cultural control & ++ & + & ++ & ++ & ++ \\
\hline
\end{tabular}

+: efficacy level of the method; - : no method available.

the fungi. Moreover, a high variability in fungi populations may be observed, for example concerning downy mildew with numerous pathotypes (Ahmed et al., 2012).

The main biological and ecological characteristics of these fungi reveal a high variability in terms of inoculum survival time, endocyclism level, climatic requirements and host genetic resistance. The occurrence (incidence) and development (severity) of a disease result from complex interactions between a pathogen, a host plant and their common biophysical and biological environment defined by soil, climate and crop management. Some interactions between fungi (e.g. phomopsis and phoma) may also impact the expression of the diseases at plant level.

Reducing the harmfulness of disease attacks on a plot in a given year is the main objective of crop protection. But reducing injuries (sporulating lesions), even in the absence of detrimental effects on annual crop production, is a way to reduce the production of primary inoculum and thus future epidemics. Therefore, the reasoning of disease control methods must consider both temporal and spatial dimensions as soon as the fungus is able to spread widely.

To avoid (or at least limit) the crop injuries (symptoms) and damages (losses of yield and quality of the harvest), farmers have three possible control strategies to trigger (Delos et al., 2004; Attoumani-Ronceux et al., 2010):

- prevent the disease risk (prophylactic methods),

- avoid the contamination when inoculum is still present,

- mitigate crop injuries and damages after infection.
The methods for cryptogamic diseases control are divided into five types:

- genetic control (through the choice of tolerant/resistant varieties);

- physical control (e.g. fumigation);

- chemical control (by the use of fungicides);

- biological control (e.g. Coniothyrium minitans against sclerotinia);

- cultural control (Aubertot et al., 2005).

These effects on sunflower diseases are presented in Table 1.

During the two previous decades, genetic control made a lot of progress for controlling sunflower diseases (Vear, 2016); nowadays, it is surely the most efficient, practical and repeatable method to control most of the diseases but breeders have to deal with new virulences that overcome specific resistance genes in farmers plots (e.g. downy mildew) and very polygenic resistances (e.g. phoma and sclerotinia). The second main method used by farmers is chemical control but only few active ingredients with preventive mode of action are available (one against downy mildew, two against phomopsis/phoma) and their efficiency is lost or insufficient. In addition, French agriculture is targetting a $50 \%$ pesticide use reduction at 2025 time horizon (Ecophyto-II national plan).

In order to decrease the application of pesticides, for environmental and public health concerns, and to preserve the sustainability of genetic resistance, agronomic control should 


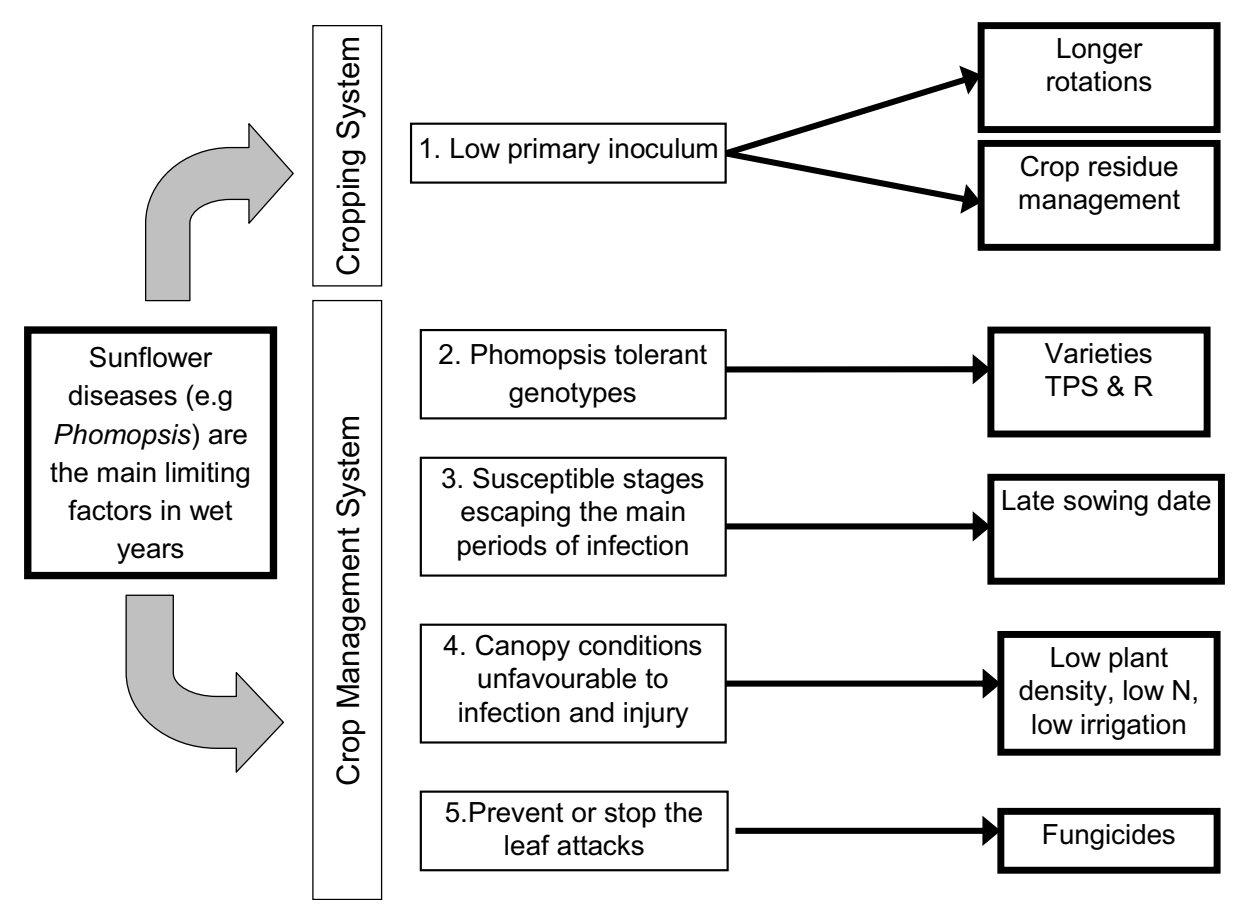

Fig. 2. A schematic diagram representing the strategies for controlling Phomopsis helianthi and the technical solutions than can be applied: 1: prophylactic methods; 2: tolerance (genetic control); 3: escape; 4: avoidance; and 5: attenuation (chemical control). Cultural control is 1 (cropping system level, before sunflower crop or on adjacent fields), 3 and 4 (crop management system, intra-field) (from Debaeke et al., 2014).

be more practised in crop protection programs (Sackston, 1992). For that, the interactions between the pathogen, its host plant, the biophysical and biological environment and crop management must be dissected and modelled in a comprehensive system approach (Desanlis et al., 2013). Several axes have been developed within the French research consortium on sunflower established in Toulouse ten years ago (Debaeke et al., 2014; Mestries et al., 2015; Mestries and Debaeke, 2016; Seassau et al., 2016):

- produce knowledge and tools useful for breeders' work, such as methods of plant phenotyping, understanding of the genetic resistance of sunflower and its drivers (QTL, expressed genes) and the structure of fungi populations (diversity, pathotypes, effectors of pathogenicity, genome); - model primary inoculum production for a better forecast of the risk of attacks;

- estimate the effects of the cultural practices on the incidence and the severity of the diseases and take into account the interactions between the environment, the cropping system, the cultural practices, the variety and the populations of pathogenic fungi at the spatial and temporal scales in order to develop decision-making tools for advisers and farmers.

\subsection{Modeling the effect of crop management on Phomopsis stem canker incidence and severity}

Among the results recently compiled by Mestries and Debaeke (2016), those relative to the agronomic control of Phomopsis stem canker significantly illustrated this integrative approach (Fig. 2).
In order to represent in an integrated way the response of a sunflower variety exposed to the entire pathogenic fungi complex, two complementary modeling avenues were explored: - a mechanistic and dynamic approach, based on the coupling of epidemiological models with the processbased SUNFLO crop model developed by Casadebaig et al. (2011). This way requires detailed knowledge on the lifes cycles of the pathogens and their interactions with their host (earliness, plant architecture, leaf area development and senescence dynamics, genetic resistance,...) and their environment (climate, soil, cultural practices). Theoretically, such a model can simulate the harmfulness of the disease for a wide range of environments;

- a qualitative approach, with no explicite representation of the biological processes, hence less demanding in detailed knowledge, but gathering literature and expertise extensively, but only focused on the prediction of symptoms and not yield loss. This approach, proposed by Aubertot and Robin (2013), is based on the IPSIM (Injury Profile SIMulator) platform, and results in the development of a family of qualitative aggregative models. The method allows to roughly simulate the effects of agricultural practices (residue management, varietal choice, fungicide control,...) and of the production situation (soil, climate and environment of the plot) on the risk of damage caused by a complex of the main bio-aggressors (diseases, pests, weeds).

These two modeling options both allow to represent the interactions between the pathogens composing the parasitic complex of the sunflower while complementing each other. Then, the structure of the mechanistic model "SUNFLO Maladies" integrating phomopsis and phoma epidemiological 
process made it possible to produce knowledge useful for the design of the IPSIM models for these two diseases such as thresholds of LAI (leaf area index) at different phenological stages favorable or not to the infections. Reciprocally, the IPSIM approach allows integrating elements not taken into account in the "SUNFLO_Maladies" model. In addition, these two models use the SÜNFLO model to predict the LAI level according to cropping practices (date and density of sowing, soil residual nitrogen and $\mathrm{N}$ fertilisation, irrigation), soil (deep or shallow) and climate (dryness or wetness for each major phase of the cycle). Their respective predictive qualities can be characterized in parallel on independent data sets.

Similarly, the output variables of "SUNFLO_Maladies" are grain yield and oil content in the presence of disease, which IPSIM_Sunflower cannot predict. On the other hand, one can imagine a variety of output variables for IPSIM_Sunflower, other than the simple incidence of the disease: a combination of incidence and severity rates (e.g. for black stem disease: percentage of plants with necrosis below or above $1 / 3$ of plant height), the amount of primary inoculum, the appearance of a new pathotype of downy mildew, etc...

These two types of models will allow developing tools to help design integrated crop protection/production strategies accessible to different users: scientists and engineers for the finer "SUNFLO_Maladies" model, or consultants and technicians for the easier to use and more accessible IPSIM Sunflower tool which is also of direct interest for education and training.

The tools for designing and assessing cultural practices for integrated sunflower production will be useful (i) upstream for breeders in the search of varietal ideotypes and (ii) downstream for advisers involved in variety testing and technical recommendations. They will also contribute to the analysis of the impact of climate change on sunflower production and the disease complex as a first step for the identification of adaptation strategies (Debaeke et al., 2017).

The sound association of cultural, genetic, chemical and biological control methods is the key for an effective, integrated and sustainable control of sunflower diseases, which constitutes one central pillar of agroecology.

\subsection{Controlling Verticillium wilt by biofumigation with cover crops}

In France, since 2010, sunflower has been severely affected by Verticillium dahliae Kleb., a vascular wilt soilborne fungus causing significant damage up to $30 \%$ yield loss (Mestries and Lecomte, 2012). Since the prohibition of effective but harmful chemical fumigants as methyl bromide, biofumigation could be an agroecological technique to manage soilborne pathogens like $V$. dahliae in sunflower crops. This process involves growing a Brassica crop during the intercrop period and then grinding it up and incorporating the residues into the soil. Currently, verticillium wilt is difficult to control because the pathogen can survive in the soil as microsclerotia (MS) for more than 10 years even in the absence of a suitable host (Griffiths, 1970; Bruehl, 1987). Thus, MS are regarded as the primary targets to control the disease. Studies have mainly investigated the potential of glucosinolates (GSLs) containing
Brassica cover crops for suppression of $V$. dahlia (Manici et al., 1997; Sarwar et al., 1998; Smith and Kirkegaard, 2002; Larkin and Griffin, 2007; Neubauer et al., 2014) and the role of isothiocyanates (ITC) related to biofumigation often cannot be interpreted because no information is provided on the type or the concentration of GSLs which vary greatly within Brassica species, plant tissues and cultivars (Mithen, 1992; Kirkegaard et al., 1998).

A preliminary study evaluated in vitro the potential biofumigation effects of five species of Brassica for their ability to reduce the development and the germination of MS of an aggressive strain of $V$. dahlia on sunflower. Cultivars of white mustard cv. Abraham, brown mustard cv. Etamine, leafy turnip cv. Avalon, forage rape cv. Mosa and oilseed radish cv. Anaconda were selected by their contrasting GSL side-chain profile and concentration in shoot and root tissues (Tab. 2). The GSL profiles of white mustard and forage rape had significant aromatic GSLs with main concentration of sinalbin in shoots and gluconasturtiin in roots respectively. The brown mustard GSLs profiles were dominated by aliphatic GSL (sinigrin) in shoots and oil seed radish by indole GSL (unknown indole 16.3) in roots. The GSLs profile of the leafy turnip biomass was more diverse including appreciable concentrations of aliphatic GSL (glucobrassicanapin), aromatic GSL (gluconasturtiin) and indole GSL (neoglucobrassicin) mainly in root biomass. To evaluate the potential toxicity of ITCs-GSLs on $V$. dahlia, MS and 10 days developed $V$. dahliae on growing media were exposed for 20 days to volatile compounds released by fresh or freeze ground plant tissues of root, shoot or a mix of the biomass in jars with an equivalent of $2 t$ of dry matter/ha (quantity of biomass usually incorporated in the field). The toxicity of ITCsGSLs on $V$. dahlia, assessed by the area under fungus progress curve (AUDPC) relating its development on the media, was reduced by 63 to $90 \%$ per Brassica compared to the control in absence of tissues (Fig. 3a, b). From developed fungus, brown mustard and leafy turnip were the most effective to reduce mycelial growth of $V$. dahliae (Fig. 3a). From MS, leafy turnip, oilseed radish and brown mustard were the most effective to limit MS germination (Fig. 3b).

The toxicity of biological compounds induced by the grinded biomass and ITC-liberating GSLs in the tissues of Brassica species towards $V$. dahliae was confirmed, which is in accordance with previous studies testing in vitro the toxicity of ITCs on soilborne fungi (Manici et al., 1997; Sarwar et al., 1998; Smith and Kirkegaard, 2002). Volatile compounds released by grinded Brassica species showed that MS germination was significantly reduced, which has not been studied before. Thus, investigate biofumigation toward $V$. dahliae inoculum could be an interesting agroecological practice to potentially reduce sunflower contaminations in the field. However, it appeared important to consider the species and the cultivars of Brassica to grow. Inhibition of fungi germination and development by grinded cover crops containing (i) sinigrin (aliphatic-GSL) produced by brown mustard, (ii) unknown indole 16.3 (indole GSL) by oilseed radish or (iii) a wider diversity of GSLs like in leafy turnip showed superior effects compared with Brassica species containing aromatic GSLs.

The variation in toxicity of different GSLs-ITCs to the fungi suggests that it exists significant scope to enhance the biofumigation potential of brown mustard, oilseed radish or maybe 
Table 2. Type and mean concentration ( $\mu$ mol.g-1 dry weight tissue) of glucosinolates in shoot and root tissues of five Brassicas biofumigant crop varieties

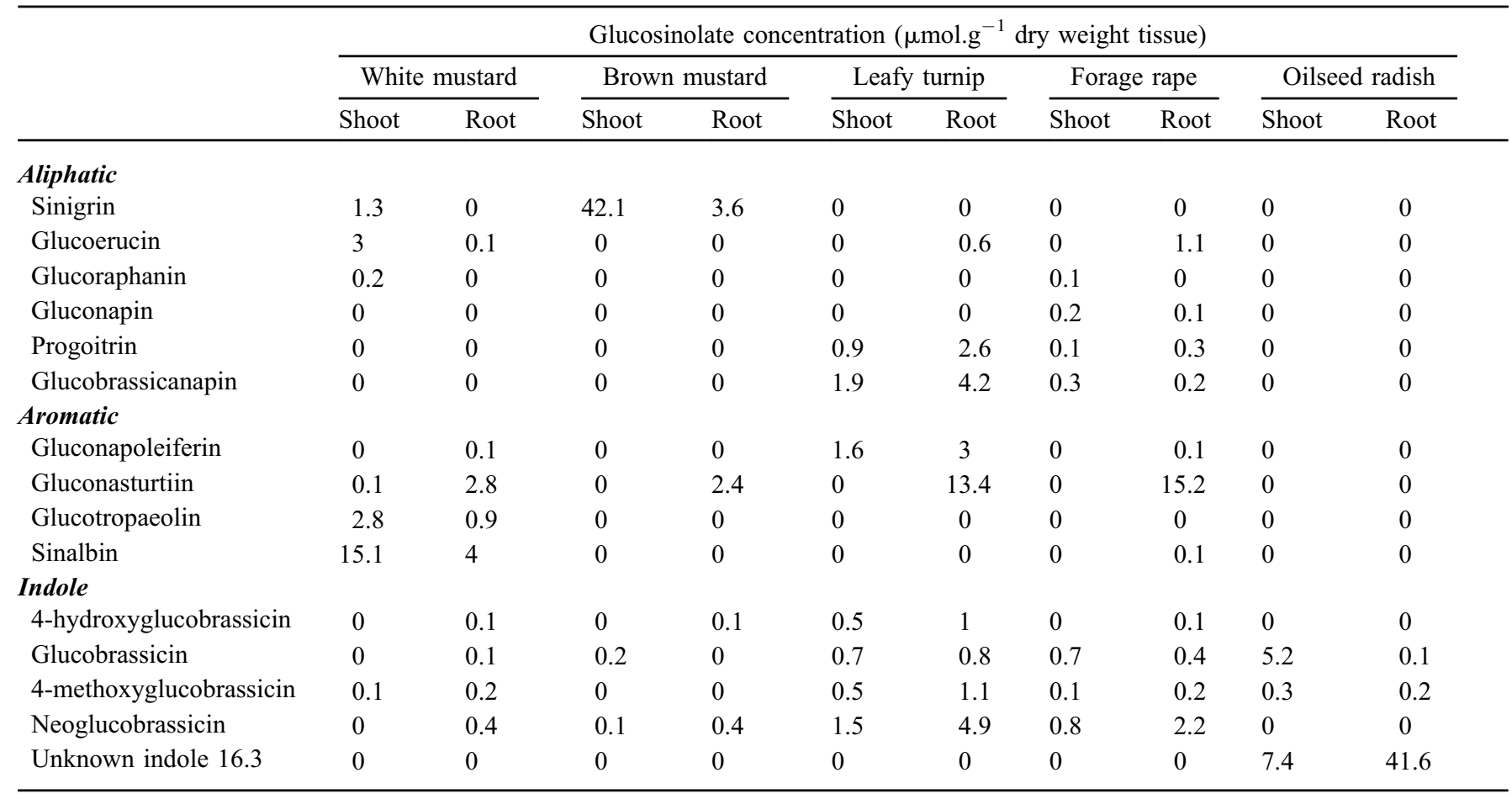
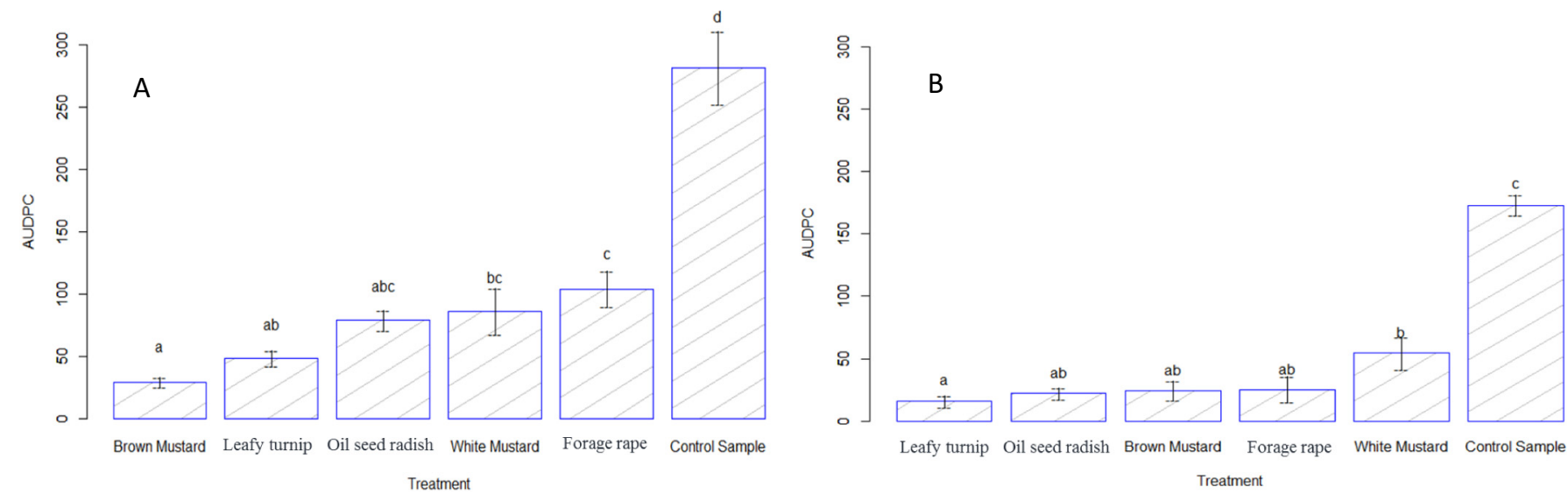

Leafy turnip Oil seed radish Brown Mustard Forage rape White Mustard Control Sample

Fig. 3. Effect of grinded root and shoot Brassica biomass on Verticillium dahliae development and germination from microsclerotia on potato dextrose agar media measured by the area under the fungus development progress curve (AUDPC) from 10 days developed fungus (A) and a plug of microsclerotia (B) on media. No biomass was brought on control treatment. Different letters indicate significant differences between AUDPC $(P<0.05) . n=30$ for each sample of Brassica.

cruciferous crops like leafy turnip producing a wider diversity of GSLs precursors to the most toxic ITCs to control soilborne disease problems and especially sunflower wilt in the field.

\section{Sunflower-soybean intercropping to improve agronomic and economic performances by increasing natural resources use efficiency}

Intercropping (IC) is the simultaneous growing of two or more species in the same field for a significant period (Willey and Osiru, 1972). This practice may look as old-fashioned but it could be considered as a way of ecological intensification providing ecosystem services. Indeed, intercropping allows the increase of natural resources use efficiency by positive interspecific interactions (e.g. Bedoussac et al., 2015). Many studies on grain legume-cereal intercrops have shown advantages over the sole crops in low input systems such as the increase of the overall yield (sum of the species) and the grain protein concentration improvement of the cereal (e.g. Bedoussac et al., 2015). In addition, intercropping warm-season crops constitutes a feasible alternative to promote hetero-geneity within-fields and therefore sustain biodiversity (weeds, 
insects) in conventional cropping systems in temperate regions (de la Fuente et al., 2014).

Relatively few researches dealing with sunflower-soybean intercropping are available, mainly based on experiments in African, Asian and South American conditions (Olowe and Adebimpe, 2009; Shivaramu and Shivashankar, 1992; Calvino and Monzon, 2009; Miao et al., 2016) and mainly focusing on the agronomic functioning and efficiency (Echarte et al., 2011; Andrade et al., 2012). These researches show that the land equivalent ratio (LER) - the surface needed in sole crops to produce the same yield as in the intercrop - was generally ranging from 1.2 to 1.6 . This confirms the agronomical advantages of intercrops in comparison to sunflower and soybean sole crops. This can be interpreted as a better niche resource complementarity for nutrients and water, based on: (i) the ability of the legume to get the atmospheric $\mathrm{N}_{2}$ thanks to its symbiotic fixation with more soil mineral nitrogen available per sunflower plant as positive consequence and (ii) the different exploration of soil layers by the two rooting systems, far deeper for sunflower (powerful tap root) than for soybean (Cabelguenne and Debaeke, 1998). Apart the analysis of ecological processes, it would be relevant to identify the most efficient row patterns of sunflower-soybean intercrops in order to improve resource use efficiency (e.g. nitrogen, water, light) and consequently to increase their agronomic performances (e.g. yield, oil concentration) and profitability.

Field experiments were performed in 2010 and 2011 both under low input rainfed conditions and non-limiting water and nitrogen availabilities in southwestern France (Inra ToulouseAuzeville) (Landé et al., 2012; Tribouillois et al., 2012). Conversely to cereal-legume intercrops that are harvested together, the sunflower-soybean intercrops are harvested in two times, such as an early harvest for sunflower and a late one for the soybean. Then the spatial row design (strip intercrops) must be adapted according to (i) the combine harvester used, and ii) the width between sunflower rows which needs to take into account the distance between the wheels of the harvester in order not to destroy the soybean plants when harvesting the sunflower. According to that, different spatial designs were evaluated: (i) $2 / 2$ design i.e. 2 adjacent rows of each species and (ii) 2/4 design i.e. 2 sunflower rows alternated with 4 soybean rows. It was assumed that the $2 / 2$ design would be more favourable to the sunflower than the second one due to the competition for light, the sunflower being higher than soybean from flowering to harvest. The choice of cultivars is another factor that may affect the complementarity of the two species. In order to improve the temporal growth complementarity between species it was initially assumed that the best combination would consist in an early-maturing sunflower and a late-maturing soybean.

Our results clearly indicated that the best performances of sunflower-soybean strip intercrops were obtained in low-input conditions (low soil mineral-N content at sowing and no irrigation) where species complementarity is fully expressed (Landé et al., 2012; Tribouillois et al., 2012). Conversely, when crops were conducted in high inputs conditions (fully irrigated and with high level of soil mineral-N content at sowing), the sole crops were found more efficient than intercrops (LER lower or equal to 1) (Fig. 4). This result is explained by the strong interspecific competitions of sunflower on soybean in particular for light capture. Intercropped

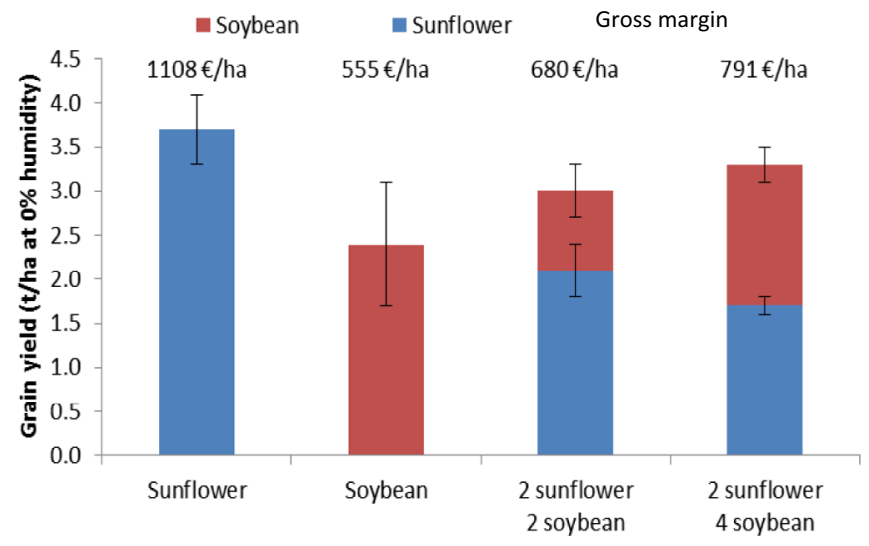

Fig. 4. Grain yield and gross margin for sole crops (sunflower and soybean) and $2 / 2$ and $2 / 4$ sunflower-soybean intercrops: Inra Toulouse-Auzeville experiment (2010)

sunflower always presented a competitive advantage over the intercropped soybean leading to low soybean yields and this advantage was increased in the $2 / 2$ design. The $2 / 4$ design was the most efficient spatial design in order to re-equilibrate interspecific competitions and optimize natural resources use. As expected, intercropping the late soybean cultivar with the earliest sunflower resulted in the best overall performance. In that case, the overall yield was higher in intercrops than for the two sole crops averaged. The highest LER was 1.24, indicating a real potential of sunflower-soybean intercrop for yield production in rainfed conditions in our pedoclimatic conditions. As hypothesized, the $\mathrm{N}_{2}$ fixation rate of the soybean was higher in the intercropped than in the sole crop due to the early uptake of mineral nitrogen by sunflower that forced the legume to fix more $\mathrm{N}_{2}$ due to the competition for soil mineral-N.

The 2/4 design was found to be economically efficient in low-input conditions because its yield performance was high enough to compensate for the increase in input costs required by both crops. For the other treatments $(2 / 2$ design and high input systems), the gross margin was depressed due to higher input costs and low soybean grain yield. We estimated that a minimum of $12 \%$ to $16 \%$ of yield increase was required in intercrop to reach the same relative gross margin as in sole crops.

Our study confirms that sunflower-soybean strip intercrops can be more efficient than the sole crops when grown in lowinput conditions. This clearly emphasized that there are various possibilities for improving interspecific interactions and the use of abiotic resources within the growth cycle. Therefore, there is a potential in exploring earliness, aerial plant architecture of genotypes for both species, but also adapting intercrop row structure and management practices (Robinson, 1984; Andrade et al., 2012). The risk of infection with pathogens common to both crops, such as Sclerotinia sclerotiorum, must be mentioned. If there is an epidemic in one crop, the other could be simultaneously affected, leading to an important loss to the farmer. To avoid this risk, fields where the risk of inoculum in the soil (sclerotia) is low should be selected in priority and crops susceptible to sclerotinia should not be planted less than once every 4 years (Debaeke et al., 2014). Nevertheless, as sunflower-soybean intercropping is 


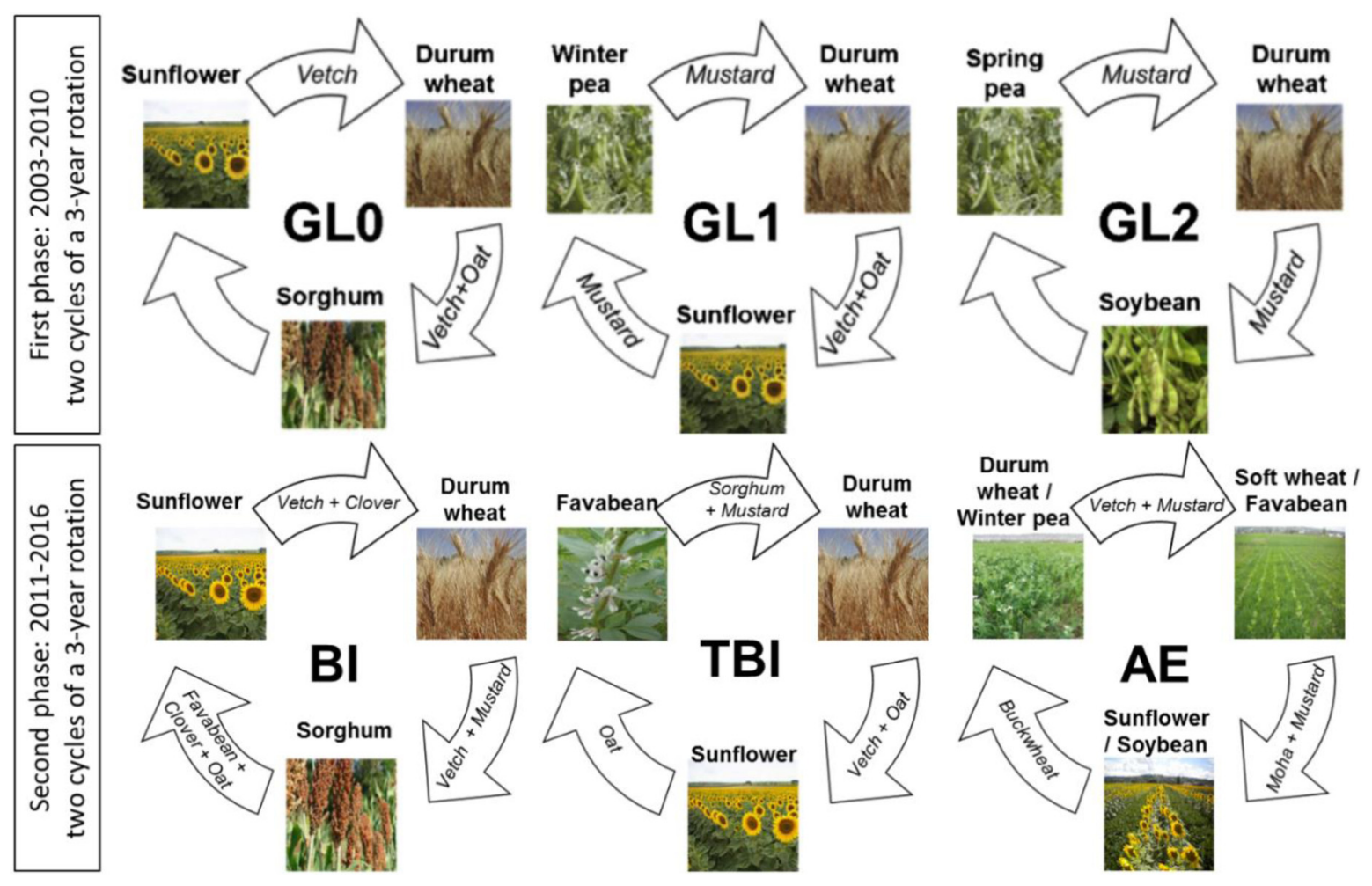

Fig. 5. Conceptual diagram of the long-term cropping system experiment (2003-2016) in Toulouse-Auzeville (Inra): each experimental phase was composed of two cycles of 3-year rotations. GL: grain legumes: 0,1/3, 2/3); BI: low inputs; TBI: very low inputs; AE: agroecology: 100\% intercropping. In the second phase of the cropping system experiment (2011-2016), sunflower was grown as sole crop after sorghum (BI), durum wheat (TBI) or as intercrop with soybean (after wheat-faba bean intercrops). The reference is the sunflower-durum wheat rotation under conventional management.

recommended in situations with low soil nitrogen, developing sclerotinia in such conditions is rather scant.

Further research based on functional intercrop analysis and genotype-environment interactions under various conditions and with different sunflower and soybean genotypes is needed for optimizing interspecific complementarities between both species in intercrop. Other legumes (e.g. alfalfa, lentil, vetch..) could be intercropped also with sunflower (Kandel et al., 1997) to increase soil cover, reduce soil erosion, add nitrogen and organic matter to the soil, and control weeds.

Finally, the use of a soil-crop model relevant for intercrops and the simulation of economic and agronomic scenarii could provide complementary approaches to experiments and agronomic analysis which could help to fully assess these innovating practices and facilitate their transfer to farmers.

\section{Sunflower response in different cropping systems differing by their degree of ecologization}

The performances of sunflower were assessed in a longterm cropping system experiment located at Inra ToulouseAuzeville (Southwestern France) on a deep silty-clay to clay soil. The experiment started in 2003 with the evaluation of six prototypes of low-input cropping systems that were modified in 2011 after two cycles of a 3-year rotation (Fig. 5). Each component of the crop rotation was present each year in order to avoid confusing effects between weather and crop sequence. From 2003 to 2010, the impacts of the insertion of grain legumes in a cereal-based rotation was evaluated (PlazaBonilla et al., 2017). During a second phase (2011-2016), innovative prototypes with different levels of agroecological practices were tested, such as: (i) low-input production (BI) aiming at reducing the use of synthetic inputs and pesticide use by $50 \%$ if possible, (ii) production at very low level of synthetic inputs (TBI) where the use of all inputs (fertilisers, pesticides) was reduced by at least $50 \%$ according to Ecophyto plan, and (iii) production based on agroecological principles (AE) (only intercrops) with the objective to reduce synthetic inputs as much as possible, without using any chemical seed treatment. These three rotations included or not cover crops during the fallow period in order to reduce nitrate leaching and $\mathrm{N}$ gaseous losses $\left(\mathrm{N}_{2} \mathrm{O}, \mathrm{NH}_{3}\right)$ and then recycle $\mathrm{N}$ at the beneficial of the main cash crops (durum wheat, sunflower, ...). The cover crops (CIMS) were also used to produce ecosystem services by substitution of chemical inputs. From 2016, a third phase will consider longer rotations. Intercropping and variety mixtures - for cash and cover crops - were used as a way of diversification and production of ecosystem services.

The 6 different prototypes based on 3-year rotations all included sunflower as a main component of regional cropping systems. Moreover, sunflower was cropped in three types of plant cover (i) mono-varietal (BI and BI CIMS), (ii) varietal mixture of 4 cultivars (TBI and TBI_CIMS), and (iii) strip intercrop with soybean (AE and AE_CIMS) as previously 
(a)

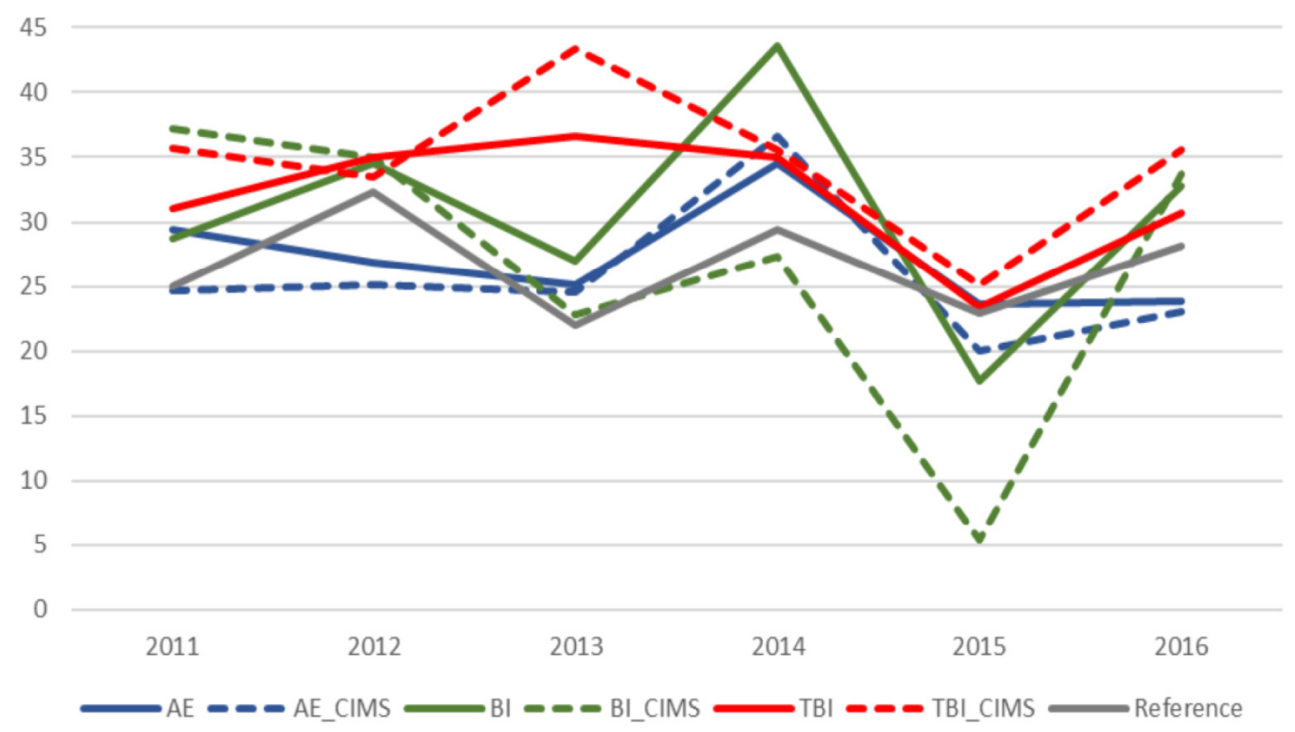

(b)

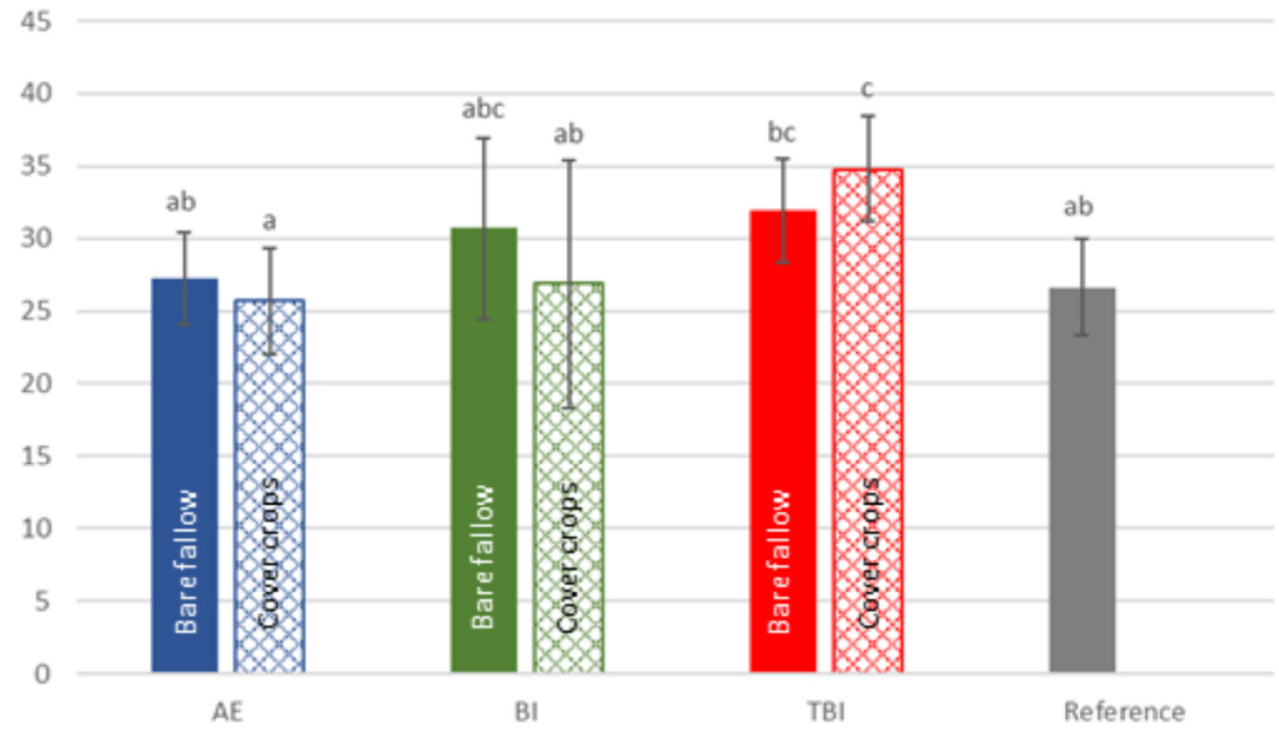

Fig. 6. Sunflower grain yields (q/ha) from 2011 to 2016 under different agroecological practices (BI: Low Inputs; TBI: Very Low Inputs; AE: agroecology; CIMS: multi-service intermediate crops). In AE, yield is for intercropped "sunflower + soybean". (a) Inter-annual variation; (b) Average sunflower grain yields over the 6 year period. Bare fallow or cover crops were introduced after the previous crops.

described (Fig. 6). Additionally, a 2-year sunflower-durum wheat rotation was introduced as the regional cropping system reference.

The main results issued from the second experiment (2010-2016) highlighted that the yields of sunflower were relatively stable according to years despite the high weather variability (Fig. 6), indicating that this crop is quite robust and resilient. The higher yields were obtained for the TBI and TBI CIMS prototypes compared to the conventional sunflower-wheat reference. Intercropping sunflower with soybean (AE and AE_CIMS) resulted in total yields equivalent to sunflower sole crops (Fig. 5).

Cropping sunflower in these conditions was nicely compatible with a significant and strong reduction of chemical inputs, without any significant decrease of yield, neither in the oil concentration of grains (and then of oil content per hectare) (Tab. 3). It can be highlighted that the insertion of cover crops in the cropping system did not reduce the yield of sunflower, and even led to the best mean yield for the TBI_CIMS prototype, indicating that the combination of adapted technical practices and the use of variety mixtures was efficient to support a good level of sunflower yield in the rainfed conditions of southwestern farming systems (Fig. 6).

The weakest economic return was obtained when intercropping sunflower with soybean (AE) due to higher costs for mechanical weeding and double harvest. However, the semi-net margin of sunflower remained pretty good and not significantly lower for the BI and TBI prototypes, but was less variable according to years. On the other hand, the semi-net margin was strongly reduced when introducing cover crops 
Table 3. Indicators of sunflower performance (grain yield, treatment frequency index (TFI), semi-gross margin (GM), oil concentration) for different cropping systems (AE, BI, TBI, Reference) on the long-term experiment of Toulouse-Auzeville (INRA). CIMS (multi-services cover crops). Numbers in italics indicate standard deviation (SD, 3 years).

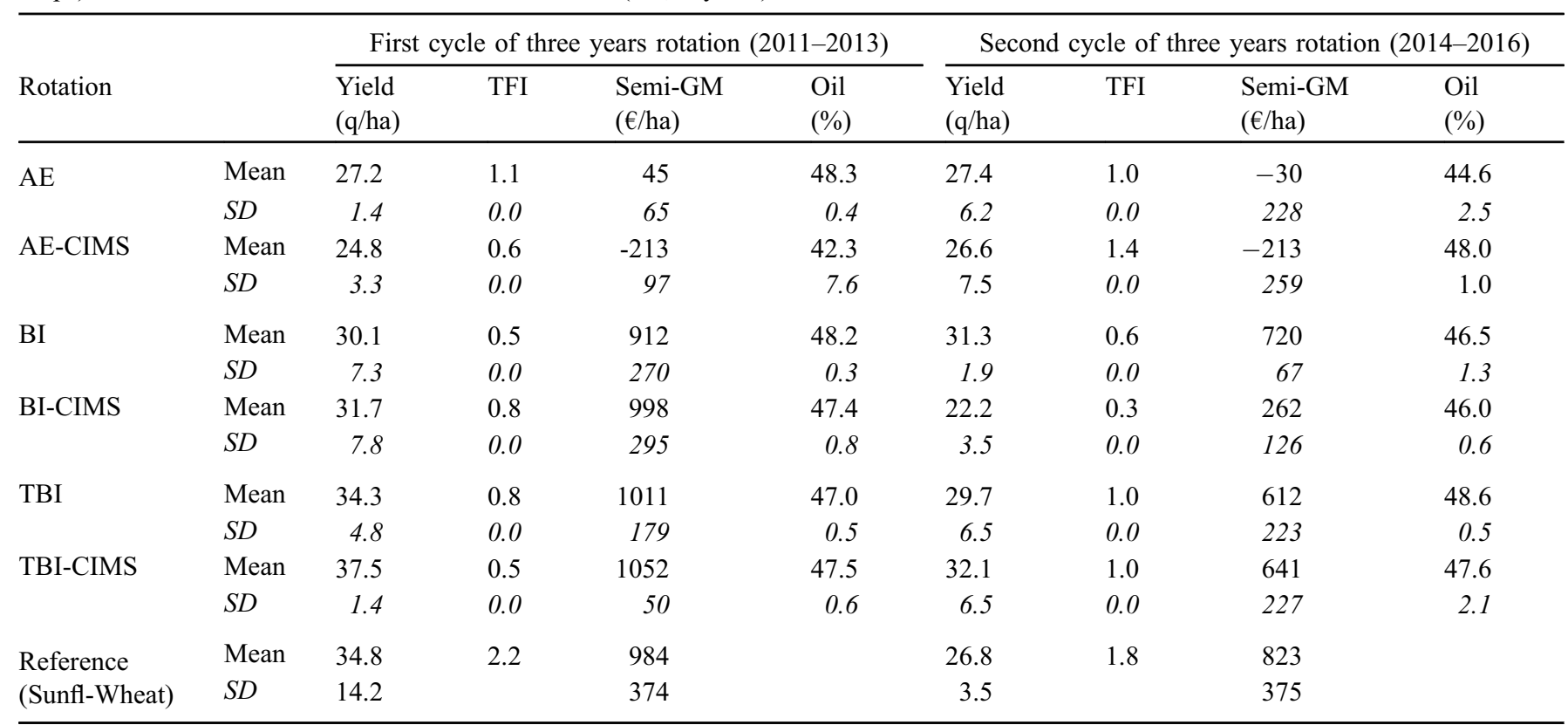

prior to sunflower, due to the operating costs for seeds and sowing not compensated by a significant increase in sunflower yield or oil content (Fig. 6; Tab. 3).

Our results confirmed that sunflower could be cropped in low-input and agroecological cropping systems with good economic performances and by decreasing the environmental impacts due to the strong reduction of chemical inputs (pesticides and NP fertiliser), as shown by the half reduction of the treatment frequency index of pesticides (Fig. 6). This confirmed previous experimental results which emphasized sunflower as the most yield-conservative crop when reducing chemical inputs (Debaeke et al., 1998; Debaeke et al., 2003; Nolot and Debaeke, 2003).

\section{Conclusions}

Previous examples illustrated how agroecological principles could be also applied to sunflower crop to improve production in low-input conditions, and enhance the ecosystem services that the crop could deliver. However, in spite of these good features, sunflower crop is not widely adopted by farmers in France except in some traditional production basins (as southwestern France) where it is probably too frequently sown. The increasing environmental constraints on pesticides and water use and the climatic evolution should obviously increase its adoption except if sunflower profitability is judged too low as compared to other productions.

Agroecological practices could perhaps be a good opportunity for closing some technical gaps in sunflower production. For instance, the influence of landscape management and permanent soil covering on birds populations and consequently crop establishment needs to be investigated. More research is under way on that topics to explore innovative non-chemical solutions. Moreover, conservation agriculture should include more sunflower to diversify the crop rotation. The use of strip-till (limited to the sowing row) as a way to minimize soil tillage while not depressing plant emergence and root growth was reported as a promising option in sunflower (Lecomte and Longueval, 2013).

More planned diversity could be introduced in the agrosystems where sunflower is frequently grown. Varietal mixtures widely attempted in cereals are an original option to explore in sunflower for increasing abiotic and biotic stress resilience. This was used in the Auzeville experiment as part of the crop management system (TBI) but it should be more thoroughly assessed in factorial experiments to identify the best varietal combinations especially for increasing the crop resilience to abiotic factors.

Intercropping sunflower with legumes (especially soybean) was tested in several countries including France. As sunflower has a rapid growth when $\mathrm{N}$ and water resources are fully available thus intercepting more radiation, the 2/4 row design should be preferred. It appears that this strip intercropping should be recommended particularly in lowinput and less fertile production situations. Sunflower could also be a component of agroforestry systems as was demonstrated in some other regions of the world (Panneerselvam and Arthanari, 2011; de Oliveira et al., 2012).

The idea of agroecology is to go beyond the use of alternative practices and to develop agroecosystems with the minimal dependence on agrochemical and energy inputs, in which the ecological interactions and synergisms between biological components enhance soil fertility, crop protection and productivity (Altieri and Rosset, 1995). Sunflower is well recognized as an environmental-friendly crop. In this paper, we demonstrated that the crop could be also a component of this agroecology-driven agriculture and that the ecosystem services it provides should be more recognized and emphasized. 
Acknowledgements. This work was financially supported through various projects (Crucial, MicMac design, SUNFLOMaladies) by the CASDAR (French Fund for Agricultural and Rural Development, Ministry of Agriculture and Forestry), Promosol (French Association for the Promotion of Selection of Oilseeds Crops), ANR (the French National Research Agency) and the Occitanie (formerly Midi-Pyrénées) region (thesis grants). The authors gratefully thanks all the technicians of UE Toulouse-Auzeville and UMR AGIR who contributed to the sunflower annual and long-term experiments with a special mention for Eric Bazerthe, Patrick Bruno, Didier Chesneau, Céline Colombet, Benoit Gleizes, Michel Labarrère, Eric Lecloux and Pierre Perrin.

\section{References}

Agreste. 2013. Les indicateurs de fréquence de traitement (IFT) en 2011. AGRESTE, Les Dossiers (18): 5-9.

Agreste. 2014. La fertilisation. AGRESTE, Les Dossiers (21): 27-47.

Ahmed S, Tourvieille de Labrouhe D, Delmotte F. 2012. Emerging virulence arising from hybridisation facilitated by multiple introductions of the sunflower downy mildew pathogen Plasmopara halstedii. Fungal Genet Biol 49: 847-855.

Altieri MA, Rosset PM. 1995. Agroecology and the conversion of large-scale conventional systems to sustainable management. Int $J$ Environ Stud 50: 165-185.

Andrade JF, Cerrudo A, Rizzalli RH, Monzon JP. 2012. Sunflowersoybean intercrop productivity under different water conditions and sowing managements. Agron J 104: 1049-1055.

Angadi SV, Entz MH. 2002. Root system and water use patterns of different height sunflower cultivars. Agron J 94: 136-145.

Attoumani-Ronceux A, Aubertot J-N., Guichard L, et al. 2010. Guide pratique pour la conception de systèmes de culture plus économes en produits phytosanitaires. Application aux systèmes de polyculture. Ministères chargés de l'agriculture et de l'environnement, RMT SdCI, 80 p.

Aubertot J-N, Barbier J-M, Carpentier A, et al., eds. 2005. Pesticides, agriculture et environnement. Réduire l'utilisation des pesticides et limiter leurs impacts environnementaux. Stratégies de protection des cultures. In : Rapport d'expertise scientifique collective. France : Inra et Cemagref, $117 \mathrm{p}$.

Aubertot J-N., Robin M-H. 2013. Injury Profile SIMulator, a qualitative aggregative modelling framework to predict crop injury profile as a function of cropping practices, soil, climate and field environment. I. Conceptual bases. PLoS ONE 8: e73202.

Babu S, Rana DS, Yadav GS, Singh R, Yadav SK. 2014. A review on recycling of sunflower residue for sustaining soil health. Int $J$ Agron: 601049.

Bedoussac L, Journet E-P., Hauggaard-Nielsen H, et al. 2015. Ecological principles underlying the increase of productivity achieved by cereal-grain legume intercrops in organic farming. A review. Agron Sustain Dev 35: 911-935.

BIO IS. 2010. Analyses de cycle de vie appliquées aux biocarburants de première génération consommés en France. Rapport final. Coordination ADEME, $236 \mathrm{p}$.

Blanchet R. 1992. Tournesol : une culture pour l'environnement. Oléoscope 9: 10-11.

Brouder SM, Gomez-Macpherson H. 2014. The impact of conservation agriculture on smallholder agricultural yields: A scoping review of the evidence. Agric Ecosyst Environ 187: 11-32.

Bruehl GW. 1987. Soilborne plant pathogens. New York: Macmillan Publishing Company.
Cabelguenne M, Debaeke P. 1998. Experimental determination and modelling of the soil water extraction capacities of maize, sunflower, soybean, sorghum and wheat. Plant Soil 202: 175-192.

Calvino P, Monzon J. 2009. Farming systems of Argentina: yield constraints and risk management. In: Sadras VO, Calderini DF, eds. Crop physiology. Applications for genetic improvement and agronomy. San Diego (California): Academic Press, pp. 51-70.

Casadebaig P, Guilioni L, Lecoeur J, Christophe A, Champolivier L, Debaeke P. 2011. SUNFLO, a model to simulate genotypespecific performance of the sunflower crop in contrasting environments. Agric Forest Meteorol 151: 163-178.

Ceccon P, Debaeke P, Gonzalez-Fernandez P. 2000. Environmental issues of sunflower. In: Proceedings of 15th International Sunflower Conference, Toulouse, 12-15 juin 2000, ISA, I, Pl.C, pp. 18-27.

Chambre d'agriculture Occitanie. 2016. Bulletin de santé du végétal : bilan 2016 tournesol. Midi-Pyrénées : Édition Aquitaine, 18 p. Disponible sur http://www.mp.chambagri.fr/IMG/pdf/BSV_bi lan tournesol 2016.pdf, accessed January 20th 2017.

Champolivier L, Debaeke P, Merrien A. 2011. Pourquoi irriguer le tournesol, une culture réputée tolérante à la sécheresse ? Innov Agron 14: 151-164.

Connor DJ, Hall A. 1997. Sunflower physiology. In: Schneiter AA, ed. Sunflower technology and production. Agronomy monograph 35. Madison, WI: ASA, CSSA and SSSA, pp. 113-182.

Craheix D, Angevin F, Doré T, de Tourdonnet S. 2016. Using a multicriteria assessment model to evaluate the sustainability of conservation agriculture at the cropping system level in France. Eur J Agron 76: 75-86.

Debaeke P, Cabelguenne M, Hilaire A, Raffaillac D. 1998. Crop management systems for rainfed and irrigated sunflower (Helianthus annuus) in southwestern France. J Agric Sci (Camb) 131: 171-185.

Debaeke P, Estragnat A, Reau R. 2003. Influence of crop management on sunflower stem canker (Diaporthe helianthi.). Agronomie 23: 581-592.

Debaeke P, Mestries E, Desanlis M, Seassau C. 2014. Effects of crop management on the incidence and severity of fungal diseases in sunflower. In: Arribas JE, ed. Sunflowers: growth and development, environmental influences and pests/diseases. New York, USA: Nova Science Pubs, pp. 201-226.

Debaeke P, Casadebaig P, Flenet F, Langlade N. 2017. Sunflower crop and climate change: vulnerability, adaptation, and mitigation potential from case-studies in Europe. OCL 24(1): D102.

Delaplane KS, Mayer DF. 2000. Crop pollination by bees. New York: CABI.

Delos M, Eychenne N, Flocher L, et al. 2004. Les méthodes alternatives pour lutter contre les maladies en grandes cultures. Phytoma Déf Vég 567: 14-18.

Desanlis M, Aubertot J-N, Mestries E, Debaeke P. 2013. Analysis of the influence of a sunflower canopy on Phomopsis helianthi epidemics as a function of cropping practices. Field Crops Res 149: $63-75$.

Duru M, Therond O, Martin G, et al. 2015. How to implement biodiversity-based agriculture to enhance ecosystem services: a review. Agron Sustain Dev 35: 1259-1281.

Echarte L, Della Maggiora A, Cerrudo D, et al. 2011. Yield response to plant density of maize and sunflower intercropped with soybean. Field Crops Res 121: 423-429.

Franco JG, Saliendra N, Sanderson M, Liebig M, Archer D. 2016. Long-term agroecosystem research: the potential for sunflower to provide multiple ecosystem services in diverse cropping systems. In: National Sunflower Association Research Forum, Fargo (ND), USA, Jan 2016. 
de la Fuente EB, Suárez SA, Lenardis AE, Poggio SL. 2014. Intercropping sunflower and soybean in intensive farming systems: evaluating yield advantage and effect on weed and insect assemblages. NJAS Wagening J Life Sci 70-71: 47-52.

Griffiths DA, 1970. The fine structure of developing microsclerotia of Verticillium dahliae Kleb. Arch Mikrobiol 74: 207-212.

Jones GA, Sieving KE. 2006. Intercropping sunflower in organic vegetables to augment bird predators of arthropods. Agric Ecosyst Environ 117: 171-177.

Jouffret P, Labalette F, Thibierge J. 2011. Atouts et besoins en innovations du tournesol pour une agriculture durable. Innov Agron 14: 59-76.

Kandel HJ, Schneiter AA, Johnson BL. 1997. Intercropping legumes into sunflower at different growth stages. Crop Sci 37: 1532-1537.

Kirkegaard JA, Sarwar M, Matthiessen JN. 1998. Assessing the biofumigation potential of crucifers. Acta Horticult 459: 105-115.

Landé N, Jouffret P, Tribouillois H, et al. 2012. Evaluating economic and technical performances of sunflower-soybean intercrop in French farming systems. In: Proceedings of the 18th International Sunflower Conference, Mar del Plata (Argentina).

Larkin RP, Griffin TS. 2007. Control of soilborne potato diseases using Brassica green manures. Crop Prot 26: 1067-1077.

Lecomte V, Longueval C. 2013. Implantation : difficile de trop simplifier en tournesol. Perspect Agric 402: 50-54

Lecomte V, Nolot J-M. 2011. Place du tournesol dans le système de culture. Innov Agron 14: 59-76.

Lieven J, Wagner D. 2012. Résultats de l'enquête 2011 sur les pratiques du tournesol en agriculture biologique. Document Cetiom (Terres Inovia), 5 p.

Manici LM, Lazzeri L, Palmieri S. 1997. In vitro fungitoxic activity of some glucosinolates and their enzyme-derived products toward plant pathogenic fungi. J Agric Food Chem 45: 2768-2773.

Mestries E, Debaeke P, eds. 2016. Dix années de recherches collaboratives : résultats marquants. In : Journées d'échanges Tournesol, 28 et 29 juin 2016, Toulouse (France), 29 p. Disponible sur http://www.terresinovia.fr/fileadmin/cetiom/regions/Sud/ PDF/2016/JourneesTournesol28_29_juin/DOSSIER_Tournesol 2016_10ans_UMT.pdf, accessed January 20th 2017.

Mestries E, Lecomte V. 2012. Tournesol et Verticillium dahliae : état des lieux et moyens de lutte pour 2013. Rencontres techniques régionales du CETIOM 2012-Sud-Ouest, 14 p.

Mestries E, Desanlis M, Aubertot J-N., Debaeke P. 2015. Une approche intégrée pour prendre en compte les effets de la variété, de la conduite et de l'environnement sur l'incidence et la sévérité des maladies de fin de cycle du tournesol. Innov Agron 46: 75-93.

Miao Q, Rosa RD, Shia H, et al. 2016. Modeling water use, transpiration and soil evaporation of spring wheat-maize and spring wheat-sunflower relay intercropping using the dual crop coefficient approach. Agric Water Manag 165: 211-229.

Mithen RF. 1992. Leaf glucosinolate profiles and their relationship to pest and disease resistance in oilseed rape. Euphytica 63: 71-83.

Neubauer C, Heitmann B, Müller C. 2014. Biofumigation potential of Brassicaceae cultivars to Verticillium dahliae. Eur J Plant Pathol 140: $341-352$.
Nolot J-M., Debaeke P. 2003. Principes et outils de conception, conduite et évaluation de systèmes de culture. Cah Agric 12: 387400.

de Oliveira ACV, de Moraes A, Ribeiro MFS, et al. 2012. The effect of shading on yield of sunflower production in agroforestry system with Eucalyptus. In: Second International Symposium on Integrated Crop-Livestock Systems, Porto Alegre, (Brazil) - 8-12 Oct. 2012, 3 p.

Olowe VIO, Adebimpe OA. 2009. Intercropping sunflower with soyabeans enhance total crop productivity. Biol Agric Horticult 26: $365-377$.

Panneerselvam P, Arthanari PM. 2011. Impact of nutrient management and agro-forestry systems on growth and yield of sunflower. Madras Agric J 98: 136-140.

Pilorgé E. 2010. Nouveau contexte environnemental et réglementaire: quel impact pour la culture du tournesol ? OCL 17: 1326-1328.

Plaza-Bonilla D, Nolot JM, Raffaillac D, Justes E. 2017. Innovative cropping systems to reduce $\mathrm{N}$ inputs and maintain wheat yields by inserting grain legumes and cover crops in southwestern France. Eur J Agron 82: 331-341.

Robinson RG. 1984. Sunflower for strip, row, and relay intercropping. Agron J 76: 43-47.

Rodriguez-Lizana A, Carbonell R, Gonzalez P, Ordonez R. 2010. N, P and $\mathrm{K}$ released by the field decomposition of residues of a peawheat-sunflower rotation. Nutr Cycl Agroecosyst 87: 199-208.

Sackston WE. 1992. Managing the major plant diseases: from cultural practices to breeding for resistance. In: Proceedings of the 13th International Sunflower Conference, Pisa (Italy), pp. 687-699.

Sarwar M, Kirkegaard JA, Wong PTW, Desmarchelier JM. 1998. Biofumigation potential of Brassicas - III. In vitro toxicity of isothiocyanates to soil-borne fungal pathogens. Plant Soil 201: 103-112.

Seassau C, Aubertot J-N, Debaeke P, Dechamp-Guillaume G, Mestries E, Muños S. 2016. Les avancées pour une meilleure gestion des principaux bioagresseurs du tournesol. In : Journées d'échanges Tournesol, 28 et 29 juin 2016, Toulouse (France), $35 \mathrm{p}$.

Shivaramu HS, Shivashankar K. 1992. Performance of sunflower (Helianthus annuus) and soybean (Glycine max) in intercropping with different plant populations and planting patterns. Indian $J$ Agron 37: 231-236.

Smith BJ, Kirkegaard JA. 2002. In vitro inhibition of soil microorganisms by 2-phenylethyl isothiocyanate. Plant Pathol 51: 585-593.

Tribouillois H, Cristante P, Estragnat A, et al. 2012. Is sunflowersoybean intercropping an efficient solution for increasing natural resources use efficiency and yield production? In: Proceedings of the 18th International Sunflower Conference, Mar del Plata (Argentina).

Vear F. 2016. Changes in sunflower breeding over the last fifty years. OCL 23: D202.

Willey RW, Osiru DSO. 1972. Studies on mixtures of maize and beans (Phaseolus vulgaris) with particular reference to plant population. J Agric Sci (Camb) 79: 517-529.

Cite this article as: Debaeke P, Bedoussac L, Bonnet C, Bret-Mestries E, Seassau C, Gavaland A, Raffaillac D, Tribouillois H, Véricel G, Justes E. 2017. Sunflower crop: environmental-friendly and agroecological. OCL 24(3): D304 